\title{
"Factors that influence the competitiveness of SMEs in the commerce and services sector in the Municipality of Palmira, Colombia"
}

\begin{tabular}{|c|c|}
\hline AUTHORS & $\begin{array}{l}\text { Lina Marcela Vargas Garcia (D https://orcid.org/0000-0002-2367-9832 } \\
\text { Jesus David Perdomo Jacanamejoy (D https://orcid.org/0000-0002-1301-9531 } \\
\text { Maria Angelica Hernandez Cordoba iD https://orcid.org/0000-0002-0353-5452 } \\
\text { Julian Mauricio Gomez Lopez (D https://orcid.org/0000-0002-2947-976X }\end{array}$ \\
\hline ARTICLE INFO & $\begin{array}{l}\text { Lina Marcela Vargas Garcia, Jesus David Perdomo Jacanamejoy, Maria } \\
\text { Angelica Hernandez Cordoba and Julian Mauricio Gomez Lopez (2019). Factors } \\
\text { that influence the competitiveness of SMEs in the commerce and services sector } \\
\text { in the Municipality of Palmira, Colombia. Problems and Perspectives in } \\
\text { Management, 17(4), 480-492. doi:10.21511/ppm.17(4).2019.39 }\end{array}$ \\
\hline DOI & http://dx.doi.org/10.21511/ppm.17(4).2019.39 \\
\hline RELEASED ON & Thursday, 09 January 2020 \\
\hline RECEIVED ON & Friday, 06 September 2019 \\
\hline ACCEPTED ON & Tuesday, 17 December 2019 \\
\hline & $(\mathrm{cc}) \mathrm{EY}_{\mathrm{EY}}$ \\
\hline LICENSE & $\begin{array}{l}\text { This work is licensed under a Creative Commons Attribution } 4.0 \text { International } \\
\text { License }\end{array}$ \\
\hline JOURNAL & "Problems and Perspectives in Management" \\
\hline ISSN PRINT & $1727-7051$ \\
\hline ISSN ONLINE & $1810-5467$ \\
\hline PUBLISHER & LLC "Consulting Publishing Company "Business Perspectives" \\
\hline FOUNDER & LLC "Consulting Publishing Company "Business Perspectives" \\
\hline
\end{tabular}

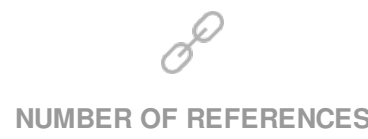

51
NUMBER OF FIGURES

2
NUMBER OF TABLES

5

(C) The author(s) 2021. This publication is an open access article. 


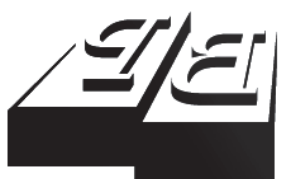

BUSINESS PERSPECTIVES

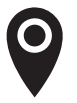

LLC "CPC "Business Perspectives" Hryhorii Skovoroda lane, 10, Sumy, 40022, Ukraine

www.businessperspectives.org

Received on: $6^{\text {th }}$ of September, 2019 Accepted on: $17^{\text {th }}$ of December, 2019

C Lina Marcela Vargas Garcia, Jesus David Perdomo Jacanamejoy, Maria Angelica Hernandez Cordoba, Julian Mauricio Gomez Lopez, 2019

Lina Marcela Vargas Garcia, Master, Professor, Universidad Santiago de Cali, Cali, Colombia.

Jesus David Perdomo Jacanamejoy, Master, Professor, Universidad Santiago de Cali, Palmira, Colombia.

Maria Angelica Hernandez Cordoba, Student, Universidad Santiago de Cali, Palmira, Colombia.

Julian Mauricio Gomez Lopez, Master, Professor, Universidad de San Buenaventura, Cali, Colombia.

\section{(ㄷ)(i)}

This is an Open Access article, distributed under the terms of the Creative Commons Attribution 4.0 International license, which permits unrestricted re-use, distribution, and reproduction in any medium, provided the original work is properly cited.
Lina Marcela Vargas Garcia (Colombia), Jesus David Perdomo Jacanamejoy (Colombia), Maria Angelica Hernandez Cordoba (Colombia), Julian Mauricio Gomez Lopez (Colombia)

FACTORS THAT INFLUENCE THE COMPETITIVENESS OF SMES IN THE COMMERCE AND SERVICES SECTOR IN THE MUNICIPALITY OF PALMIRA, COLOMBIA

\begin{abstract}
This study seeks to analyze and describe the business dynamics of small and mediumsized enterprises (SMEs) in the commerce and services sector in the municipality of Palmira, Colombia. In addition, it aims at analyzing the organizational characteristics (internal and external) to determine the factors that influence the strengthening of the variables that make them more or less competitive. The study used the estimation of an econometric model and data from 219 SMEs registered with the Chamber of Commerce $^{1}$ - Palmira 2017. In addition to several investigations with similar claims that seek to study the variables that relate to organizational competitiveness and how this aspect is classified as a fundamental factor in the state of success or business failure in the world, it was found that variables such as the contribution that technical support programs make to strengthen the SMEs.

Good management and knowledge of the financial situation of the company and the correct management of relations with suppliers are the variables that most influence the dynamics and internal and market behavior of companies in Palmira.

It is evident that more than $40 \%$ of the companies surveyed have not been trained in issues associated with competitiveness, which indicates that there are weaknesses related to the synergies that should exist between the SMEs and the institutions that provide technical support. Consequently, companies that have received training are expected to receive higher sales from the strategies learned in these trainings.
\end{abstract}

Keywords

organizational behavior, support programs, planning, differentiating factors, Palmira, Colombia

\section{JEL Classification M10, D23, L22}

\section{INTRODUCTION}

Since the creation of Law 1014 of 2006, which seeks to promote the culture of entrepreneurship, entrepreneurial activity in Colombia has increased considerably, with micro, small, and medium enterprises (MSMEs) being an important factor for the national economy because it generates $80 \%$ of employment and participates in 35\% of Gross Domestic Product (GDP) and constitutes $90 \%$ of the productive sector of Colombia, according to information from the DANE (Administrative Department of National Statistics, 2016). Currently, in Latin America, MSMEs constitute 99\% of the companies in Colombia (ECLAC, 2016). In relation to large companies, their productivity is extremely low, and they have difficulties in adapting to the constant changes offered by the market, which generates a high rate of business mortality.

1 It is an autonomous entity, with legal status and non-profit constituted by the initiative of the Palmira (Colombia) merchants. It provides them legal advisory and support in their business activities through public records. 
The challenge facing MSMEs in Latin America in the face of accelerated technological transformation leads to modifying the production processes adapting to new consumption patterns, forcing the companies to redefine their competitiveness strategies, and governments to update the promotion policies. According to Vélez, Restrepo, Garzón, and Méndez (2005), a long-lasting company is one that presents superior financial results over time, which obtains efficient performance in its management due to the coherence in its action, the identification of its sectorial environment and its government policies, avoiding morbidity states that hinder their profitable growth and that can reach thematic states.

According to Dominguez (2014), the president of Confecámaras², on average, three years after their creation, $25.9 \%$ of Colombian companies in the commercial sector and $14.94 \%$ of the service sector go through the so-called "Valley of Death," which is the moment in which a company is scarce in capital or credit resources that give the initial drive to enterprises, likewise Domínguez (2013) ensures that the MSMEs presented $80 \%$ business mortality rate. The implementation of strengthening programs has reduced this index by $26 \%$.

According to Cámara de Comercio de Palmira (2016), small businesses had 6\% (398) representation in the market and medium ones 1\% (99), of which 222 are part of the commerce sector and 37 of the services sectors. The government-promoted business strengthening plans seek to establish the strategies that lead to the consolidation of companies belonging to various economic sectors, especially those in the services sector because they do not require high initial capital. However, although the various shortcomings of SMEs have been identified, it is also important to identify the organizational characteristics of these companies in the Municipality of Palmira.

In this sense, the following research problem arises: what are the organizational characteristics of SMEs in the commerce and services sector in the Municipality of Palmira that allow determining the factors that influence the strengthening of the variables that make them more or less competitive?

This study seeks to determine the variables that most influence internal and market dynamics and behavior in companies in Palmira through an econometric model, which positively or not influence strengthening their competitiveness. To achieve this, throughout this article, 4 sections will be found, beginning with a literature review, followed by the methodology, presentation, and analysis of the results obtained and, finally, by the conclusions.

\section{LITERATURE REVIEW}

\subsection{Organizational competitiveness}

Those companies that last over time do so because in one way or another, they are competitive in the market and their niche keeps them sustainable (Marín, 2015). However, it is important to create the competitive advantages that ensure their sustainability, and do not decline when there are periods of changes in the market (Lo, Wah, \& Ramayah, 2016). According to Porter (2015), the competitive advantage is a characteristic that the company has, which differentiates it from its competitors, creating a unique offer where it allows the customers to prefer it, based on two main factors: differentiation (make products and services different from the competition) and the decrease in costs (have more efficient strategic actions than competitors).

The absence of competitive advantages in companies is one of the main reasons why MSMEs tend to have high mortality rates, in addition to the causes such as the difficulty in accessing the financing (Balcázar, 2015), the lack of differentiation, the capacities to face changes in the market and the lack of strategic planning, raised by authors such as Borrero (1998), Florez (1998), Carrillo (1998), Hernández, Mendoza, and González (2017).

2 Colombian national organization that coordinates and provides assistance in the development of its functions to the Colombian Chamber of Commerce, among others, the public functions delegated by the state. 
According to Florez (1998), MSMEs make goods and services markets more competitive, as they contribute to decentralizing economic activities; they are less capital intensive, so they boost national savings.

Making different decisions affects the external and internal customers (stakeholders), therefore, the impact caused on them affects the level of competitiveness in the company (Cunha \& Moneva, 2018; Khakpour, Kazemi, Tavakkoli, \& Fazli, 2018; Almeida \& Vieira, 2013; Kantis, Angelelli, \& Moori, 2004; Priego, Manzaneque, \& Banegas, 2013).

\subsection{Factors related to organizational competitiveness}

Strategic planning is the main factor that influences the competitiveness of MSMEs. From it, the resources that the company currently has and those that it lacks and that it needs to grow are analyzed, as referenced by Mora, Vera, and Melgarejo (2015) and Othman, Arshad, Abdul, and Mohd (2015). Through this, effective strategies are developed that directly impact the client thanks to the use of resources such as technology (Sanchez \& Jimenez, 2007), R\&D, and marketing tools.

To develop a good strategic planning, it is required that the company has a qualified human capital capable of performing the efficient processes aimed at the development and growth of the organization.

The growth of a company at the organizational level depends on the entrepreneurial orientation, which is defined as the strategy development processes that offer the organizations the basis for the decisions made and entrepreneurial actions (Rauch, Wiklund, Lumpkin, \& Frese, 2009) carried out based on a good organizational environment (Fraj, Matute, \& Melero, 2014; Meyer \& Allen, 1991; Wheel, 2014).

To do this, according to Ahumada and Perusquia (2015), it is important to recognize that the most valuable asset within the company is its intellectual capital (Calantone, Cavusgil, \& Zhao, 2002) because it is the asset with the highest degree of difficulty to imitate, this being a differentiating factor of the company. So it is necessary to keep the employees constantly trained, providing the necessary skills to always be at the forefront of sudden market changes (Husain, Dayan, \& Benedetto, 2015; Martins, Costa, \& Neves, 2018; Batista, Kilimnik, \& Reyes, 2016; Fonseca, Porto, \& Barroso, 2012; Criollo \& Montoya, 2014).

Having highly trained staff allows creating the effective strategies that generate the impact on the customer and loyalty to the company, that is, create top of mind, which are the issues that the marketing area should be responsible for because in this area, everything related to advertising and promotion of both products and the company in general is found (Lamb, Astudillo, Carpio, Delgado, \& Amón, 2011).

Additionally, another responsibility of the marketing area is to carry out the constant market research, taking into account those adjustments that are totally necessary in the product and service, to make an impact on the real needs of the client through innovation (Zandoval \& Ari, 2014; Latunreng \& Hesti, 2018; Peixoto de Paiva, 2005; Barbosa, Souza, Chaves, \& Santos, 2017; Rivera, 2015).

On the other hand, it is found that the support from institutions trained in the entrepreneurship and competitiveness area to provide the sustainability tools to entrepreneurs allows them to know their shortcomings and design and implement the action plans for mitigation and solution of real problems. This helps create the competitive advantages and last in the market (Rivera \& Rojas, 2019).

\section{METHODOLOGY}

From the list of companies that the Palmira Chamber of Commerce has in its updated database to 2017, and based on a stratified probabilistic sampling (margin of error: 5\%, confidence level: 95\%), the survey was done to 209 SMEs, from which $58 \%$ belong to the service sector and the remaining $42 \%$ to the commerce sector. 121 surveys were conducted on SMEs in the services sector (105 surveys on small businesses and 16 surveys on medium-sized companies) and 88 surveys on SMEs in the commercial sector (76 surveys on small businesses and 12 surveys on medium-sized companies) 
This article seeks to analyze the factors that influence the competitiveness of SMEs in the commerce and service sector in this city, therefore, the first thing done was to perform an analysis of the organizational characteristics, for this, the survey was used that consisted of 35 questions, which highlighted the factors related to the characterization of the company, financial, marketing, technologies, quality, and human resource management.

In business dynamics today, marked by technological advances that minimize the costs of interaction with customers, sales are consolidated as a fundamental element for the competitiveness of firms. In this sense, the dynamics of sales is decisive for the generation of income with which the completeness of the productive cycle is achieved (León, 2012). It is then pertinent to identify the degree of incidence that certain variables have on the strength of sales.

In order to estimate the factors that affect the sales, the survey information that has a sample size of 209, observations belonging to companies in the sectors in question was used. Annex 1 shows Cronbach's Alpha, which allows identifying the consistency of the survey in terms of the variables used in statistical modeling.

The variables that were defined in the theoretical framework as fundamental for sales and of which information is found in the survey are defined in Table 1. It should be remembered that the company's sales were established as a proxy variable for business competitiveness. From each of the variables, its nomenclature and structure are identified.

It can be seen that the identified variables are associated with the elements of competitiveness described in the theoretical framework. The size of the company is a control variable that implies a direct relationship with the sales force. The type of company and the economic sector are variables with which it is intended to know if belonging to a sector or a type of company influences the income derived from sales.

On the other hand, among the explanatory variables, there is a group of them that refer to the external collaboration that the companies receive from exogenous institutions. Institutional support and being a beneficiary of support programs for competitiveness are the proxy variables of institutional networks that theoretically generate the advantages in the channeling of customers and sales.

Variables associated with the company's relationship with its customers are also taken into account in terms of the communication it has with them. This variable is related to fundamental aspects of marketing that affect the competitiveness.

The market to which the company is directed is theoretically related to its dependence on the local market. On the other hand, the investment variable, especially in technology, is indicative of the intention of innovation of productive organizations, a requirement to strengthen the sales and survive in the market.

Table 1. Definition of variables object of study

Source: Authors.

\begin{tabular}{|c|c|c|}
\hline Variables & Theoretical works & Description \\
\hline \multicolumn{3}{|c|}{ Dependent variable } \\
\hline Sales or gross income & León (2012), Akben-Selcuk (2016) & Less than 100 million, more than 100 million \\
\hline \multicolumn{3}{|c|}{ Explicit variables } \\
\hline Company size & \multirow{3}{*}{ Saavedra (2012) } & Microenterprise, small company \\
\hline Type of company & & S.A.S*, others \\
\hline Economic sector & & Services, commerce \\
\hline Institutional support for competitiveness & \multirow{2}{*}{ Solleiro and Castañón (2005) } & Yes, no \\
\hline Beneficiary of accompaniment programs & & Yes, no \\
\hline Communication with client & \multirow{2}{*}{ Saavedra (2012) } & It does not have one, once a week, once a month \\
\hline Target market & & Regional, national, local, international \\
\hline Financial management & Rubio and Aragón (2006) & Internal, external \\
\hline Investment in technology & De la Cruz et al. (2006) & Yes, No \\
\hline
\end{tabular}

Note: *The Simplified Stock Company, its acronym in Spanish (SAS) is a capital company constituted by one or more natural or legal persons that, after being registered in the commercial register, is constituted as a legal entity other than its shareholder or its shareholders, and in which Members will only be responsible up to the amount of their contributions. 


\section{PRESENTATION AND RESULTS ANALYSIS}

\subsection{Strengths and organizational weaknesses of SMEs in the commerce and services sector in the Municipality of Palmira}

In this article, some characteristics were identified through the methodological development, such as strengths or weaknesses that, like the government and other different institutions, have sought to strengthen in SMEs in their different areas, therefore, those consultancies that are expensive are given to them free of charge, allowing improving the processes and increasing their productivity. (Morales \& Castellanos, 2007, Law 590, 2000).

Due to the aforementioned characteristics, it can be inferred that one of the reasons why the competitive advantage of these companies is weak, based on the definition given by Porter (2015), is because of the lack of research and planning, which leads to non-innovation, therefore, these are not differentiated from their competitors, which leads to a lack of creation of a unique offer, where they get the customers to prefer them. However, this research finds that the location, the quality of the product, and/or service and the price are some of the variables that make them survive in the changing market. On the other hand, the quality in terms of the product or service offered by the company and thanks to its personalized service modality, this element is considered as a close relationship in the client-company relationship, which generates the customer loyalty (Fraj, Matute, \& Melero, 2014; Meyer \& Allen, 1991; Kantis, Angelelli, \& Moori, 2004; Rueda, 2014).

In other sections, SMEs are characterized as the companies with high levels of work pressure, however, their collaborators create a favorable climate and interpersonal relationships are closer due to the interdependence of the functions performed, which allows the easier performance of group dynamics, the motivation of the collaborator to work with credibility, facilitates the communication, among others (Porter, 2008).
On the other hand, the organizational climate depends on the culture, which, according to Fraj, Matute, and Melero (2014) when it is oriented to learning does not directly influence the competitiveness of the organization but does so indirectly through the development of innovations. In the same sense is the location variable that conditions the number of customers to handle in the same space and period of time, being attractive because of the proximity, which makes the customers prefer them. Being located in a strategic sector, where potential competitors are also found, allows comparing with them and creates the competitive advantages (Latunreng \& Hesti, 2018).

In accordance with the influencing factors in business sustainability, companies currently have the shortcomings in innovation, technification, financing, and mainly in administrative processes. Since the innovation variable is not present, companies can fall into morbidity stages because they offer the products equal to that of the competition or without added value that makes them competitive in the market. At the time of innovation, factors such as commercial function, financing, relationship, entrepreneurship, location advantages, market potential, and growth of the leading industry group must be taken into account (Colgan \& Baker, 2003). Innovating allows the company to adapt to market changes both regionally and nationally, thus becoming a strategic tool for the company (Distanont \& Khongmalai, 2018; Rivera, 2015).

According to Barbosa, Souza, Chaves, and Santos de Varge (2018), the most important competition factor is commercial performance in the market, rather than selling innovation, since it is the most complicated for them. Incurring the high costs is another common mistake that SMEs in the commercial sector make because they do not perform stock analysis, therefore, they do not keep control of these, according to Atnafu and Balda (2018), to carry out the inventory management, which is controlled and organized, creates the competitive advantages for the company.

Additionally, and although the SMEs in Palmira mentioned that they aim at impacting the regional market, being understood as a vision of positioning, growing, and expanding, most of these 


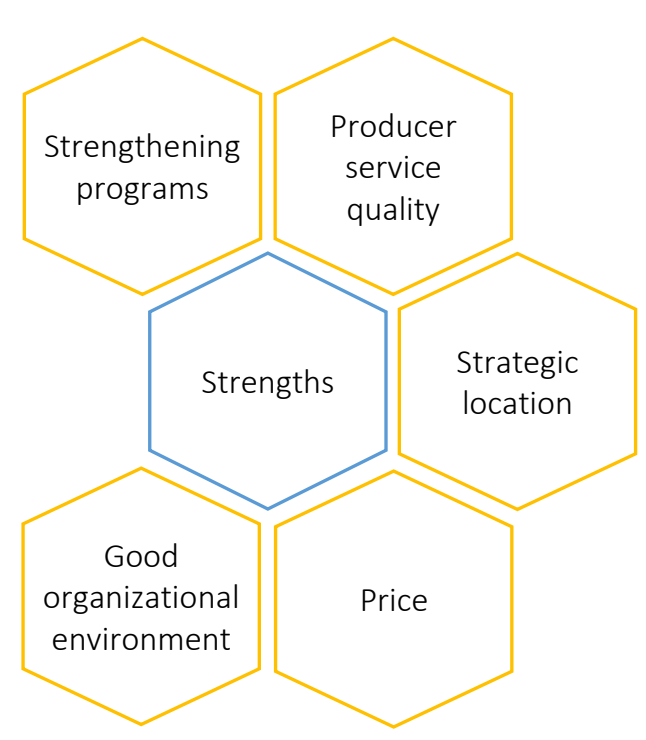

Source: Authors.

Note: Based on the quantitative study for the determination of the factors with the greatest impact on the results of SMEs in the City of Palmira, in this case, the analysis of the elements characterized as strengths for them.

Figure 1. Organizational characteristics of SMEs in the commerce and service sector of the Municipality of Palmira - strengths

consider strategic planning as a secondary activity to be carried out, limiting their possibilities. According to Mora, Vera, and Melgarejo (2015), strategic planning is one of the main factors to establish the competitiveness of a company. To do this, the formation of the ideal intellectual capital is needed, which is another characteristic that SMEs do not strengthen, because training is not carried out.

In this sense, Calantone, Cavusgil, and Zhao (2002) argue that the orientation to learning consists of four dimensions: commitment to learning, ability to exchange knowledge within the organization, shared vision, and open mind. Organizational learning is an important instrument in modern markets to provide the value to the customer and improve the organizational performance through an efficient competitive strategy design and flexible adaptation to the rapid evolution of the market (Santos, Lopez, \& Trespalacios, 2011).

According to the analysis carried out in the SMEs of the sample, it is considered a weak aspect, considering planning as a secondary process, for this reason, there is no design of action plans, which, in turn, according to Mora, Vera, and Melgarejo (2015), makes it difficult to meet the goals, growth, and expansion, ignoring the advantages that this important aspect brings, ranging from the de- velopment and implementation of strategies and tools that allow using and controlling the financial resources and increasing the performance levels of the organization (Hernández, Mendoza, \& González, 2017).

For Dean, Holmes, and Smith (1997), SMEs that enter the market with a low level of competitiveness, associativity is an option that helps them seek benefits, such as the generation of policies that generate tax advantages. On the other hand, the initial capital of SMEs in the commerce and services sector is limited, which prevents the design of large strategies, therefore, many focus on the economic constraint and do not project the expansion in their daily activities. Marín (2015), Cordero, Astudillo, Carpio, Delgado, and Amón (2011), Colgan and Baker (2003).

In relation to these aspects, Calantone, Cavusgil, and Zhao (2002) mention another determining element, such as intellectual capital that can be considered as the advantage with the highest level of imitation difficulty, and is one of the few that is strengthened in this type of organizations (Martins, Costa, \& Neves, 2018). Therefore, the administrative process as it is well known is composed of elements such as planning, organizing, directing and control. However, SMEs are not organized by objectives, which, in turn, generates 


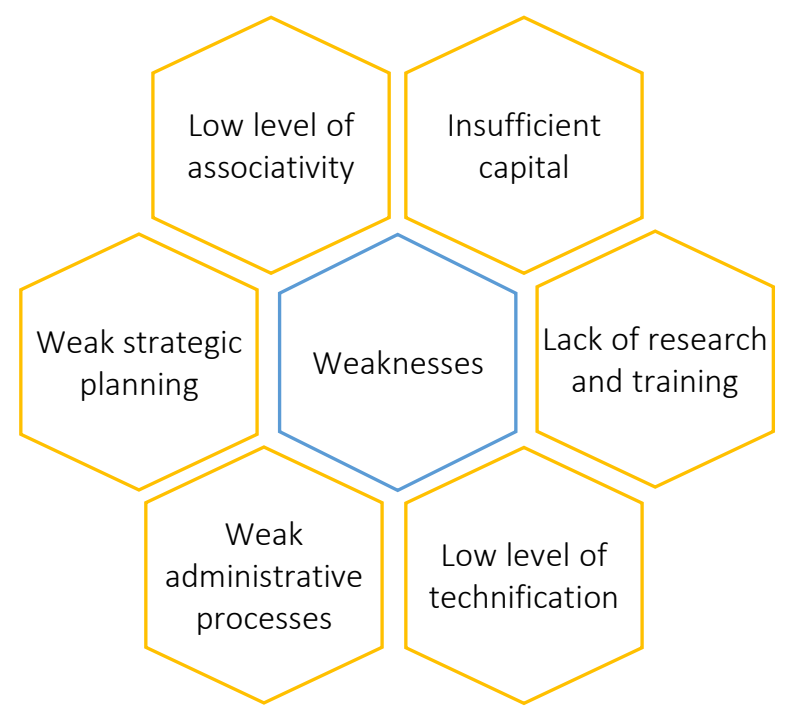

Source: Authors.

Note: Based on the quantitative study for the determination of the factors with the greatest impact on the results of SMEs in the City of Palmira, in this case, the analysis of the elements was characterized as their weaknesses.

Figure 2. Organizational characteristics of SMEs in the commerce and service sector of the Municipality of Palmira - weaknesses

the lack of goal setting and their focusing, and possibly generates blurring for growth.

And finally, because SMEs do not have the financial resources to acquire the cutting-edge technology, they must resort to the development of their activities with information or procedures that could be considered obsolete, (Sánchez \& Jiménez, 2007; Latunreng \& Hesti, 2018; Cordero et al., 2011; Husain, Dayan, \& Benedetto, 2015; Mora, Vera, \& Melgarejo, 2015).

\subsection{Characterization of the variables of competitiveness and statistical inference}

First, the dependent variable is statistically described, in this case, the sales force. It is observed that $74 \%$ of companies have sales of more than 100 million pesos per year, the remaining $26 \%$ between 25 and 100 million. It is also interesting to identify that $0 \%$ obtained revenues of less than 10 million pesos annually. Based on this information, it is interesting to determine the magnitude of the incidence of the variables defined on the strength of sales, a fundamental factor for the benefits and competitiveness of the company.

It can be seen that $88 \%$ of companies that sell less than 100 million pesos per year are microenterprises, while $73 \%$ of those that sell more than 100 million pesos annually are small, which implies in the first instance the expectation that the larger the company, the greater its sales.

As mentioned in the methodology, explanatory variables associated with the incidence of external factors on the dynamics of the company were also taken into account, one of them institutional support for competitiveness. This binary variable defines whether the company has received training or not in matters of competitiveness from institutions outside the firm. Companies that have received training are expected to receive higher sales from the strategies learned in these trainings.

It is evident that $58 \%$ of the companies surveyed have received training, which shows that high percentage $(42 \%)$ of the companies surveyed have not yet been trained in competitiveness issues, a clear sign that there is weakness in the inter-institutional relationship between the companies and institutions responsible for these trainings.

In Table 3, it is evident at the sample level that the institutional support recipient companies have higher incomes than the non-recipient companies. $71 \%$ of the companies that have been trained have income of more than 100 million pesos and $79 \%$ of those that have not been trained receive income of less than 100 million. 
Table 2. Contingency matrix between sales and institutional support

\begin{tabular}{l|c|c}
\multicolumn{2}{c}{$\begin{array}{c}\text { Source: Prepared by the authors based on the survey } \\
\text { "Profile of SMEs in the trade and services sector 2018." }\end{array}$} \\
\hline \multicolumn{1}{c}{ Sales } & Institutional support \\
\cline { 2 - 3 } & Yes & No \\
\hline Less than \$100 annual millons & $21 \%$ & $79 \%$ \\
\hline $\begin{array}{l}\text { More than \$100 millon } \\
\text { annually }\end{array}$ & $71 \%$ & $29 \%$ \\
\hline
\end{tabular}

Benefit programs for companies are provided by different institutions, among which is Bancoldex, Fondo Emprender, Procolombia, among others. The institution that contains the highest percentage of beneficiary companies is the Progress Foundation, 43\% of the surveyed companies claim to be beneficiaries of some program of that institution. On the other hand, Procolombia and Proexport are the ones with the lowest incidence.

The results of both the observed and expected frequencies and the statistic for the hypothesis contrast are evidenced. As with the institutional support variable, in this case, the hypothesis of independence between sales and being a beneficiary of programs is rejected, indicating that being a beneficiary of a program of the aforementioned institutions positively affects the competitiveness of the business.

Another variable to consider is the communication of the company with its customers. It is observed that companies communicate regularly with them once a week, which would be considered positive as long as the communication is effective, an aspect that is not evident in the survey. However, the fact that a percentage higher than $80 \%$ communicates once a week with its customers is indicative of the purpose of consolidating a stable relationship with them.

The company's target market is another essential element of the communication of the company with customers, additionally, it is a variable that indicates the level of dependence that the company has on its local market. In that sense, sales are expected to be enhanced, as firms have wider markets to offer their products. It is clear that the companies that achieve the internationalization of their production pro- cess are not the majority. However, companies are not dependent on their local market (city), the majority (45\%) has influence on the regional market (department), followed by the national destination (35\%).

A fundamental factor to achieve greater competitiveness is the internationalization of the target market to which the products or services from the company are directed (De la Cruz et al., 2006). It is assumed that companies that manage to expand their markets outside the borders of the country of origin have less dependence on local demand, which would imply strengthening the company's sales. It is interesting to highlight that $100 \%$ of the companies that internationalize their market achieve the sales of over 100 million pesos, a result that would imply a statistical relationship at the population level with both variables.

On the other hand, the variable financial management is analyzed, with which it is intended to determine whether or not the companies that perform internal management of their finances restrict their sales potential due to the opportunity cost involved in that decision. It is evident that the percentage of companies with sales greater than 100 million pesos is higher when they delegate the management of their finances to external institutions.

Another variable taken into account as an explanatory of sales was the investment in technology. From the point of view of economic theory, technological advances allow greater productive efficiency in the companies and the expansion of their products in the market, resulting in higher sales. It is evident that $70 \%$ of the companies surveyed claim to have made investments in technology in the last year.

\subsection{Econometric model}

After the descriptive and inferential analysis, the estimation of an econometric model is developed that allows observing the degree to which each of the explanatory variables is related to sales, leaving everything else constant, unlike the ChiSquare test that allows identifying only if a couple of variables are independent from each other. 
Due to the nature of the dependent variable, which takes the values of 1 (sales of more than 100 million pesos) and 0 (sales of less than 100 million pesos), the econometric estimation method that best adjusts according to the specification defined in equation (1) is the logit. The above is supported by observing the values reported in the Akaike and Bayesian information criteria, the decision rule being the choice of the model with the lowest statistic. However, although the logit model presents a linear transformation in the variables, the probabilities of occurrence of the event under study are not linear. In addition, the logit model assumes that the logarithm of the odds ratio is linearly related to the explanatory variables, and in this way, the regression coefficients express the change in the logarithm of the probabilities, when one of the explanatory variables changes in a unit and the others remain constant.

$$
\begin{aligned}
& P\left(\text { Sales }_{\text {gross }_{i}}=1\right)= \\
& =F\left(\begin{array}{l}
\beta_{1} \text { Number }_{\text {employees }_{i}}+ \\
+\beta_{2} \text { Beneficiary }_{\text {program }_{i}}+ \\
+\beta_{3} \text { Communication }_{\text {employees }_{i}} \\
+\beta_{4} \text { Communication }_{\text {provider }_{i}} \\
+\beta_{5} \text { Support }_{\text {institutions }_{i}}+ \\
+\beta_{6} \text { Sector }_{\text {economic }_{i}}+ \\
+\beta_{7} \text { Type }_{\text {company }_{i}}+ \\
+\beta_{8} \text { Investment }_{\text {TIC }_{i}}+ \\
+\beta_{9} \text { Management }_{\text {financial }_{i}}+ \\
+\beta_{10} \text { Situation }_{\text {financial }_{i}}
\end{array}\right)
\end{aligned}
$$

Table 3. Information criteria

\begin{tabular}{l|c|c} 
& & Source: Authors. \\
\hline \multicolumn{1}{c}{ Statistic } & Logit & Probit \\
\hline Observations & 222 & 222 \\
\hdashline Log-likehood & -71.682 & -72.635 \\
\hline Pseudo $R$-square & 0.44 & 0.43 \\
\hline Akaike & 167.364 & 169.271 \\
\hline Bayesiano & 208.196 & 210.103 \\
\hline
\end{tabular}

In order to evaluate a series of explanatory variables that contribute to the analysis of sales made by the companies under study, a total of 10 variables were incorporated procedurally (Table 5), some of them reported the statistical significance and the sign that would be expected according to the economic institution. The above results in a set of 8 models are reported in Table 6. In addition, when observing the pseudo $R$-square, the evaluation of these variables provides the predictive power to the estimated models, since it went from $29.4 \%$ to $43.8 \%$.

Table 4. Functional form

\begin{tabular}{|c|c|}
\hline Variables & Funcional form \\
\hline Gross sales & $\begin{array}{l}1=\text { "100 million or more"; } \\
0=\text { "Up to } 100 \text { million" }\end{array}$ \\
\hline Number of employees & $\begin{array}{l}1=\text { " } 10 \text { or less"; } \\
2=\text { "Between } 10 \text { and } 20 " ; \\
3=\text { " } 20 \text { or more" }\end{array}$ \\
\hline Program beneficiary & $\begin{array}{l}1 \text { = "Yes, we have been a beneficiary"; } \\
0=\text { "We have not been a beneficiary" }\end{array}$ \\
\hline $\begin{array}{l}\text { Customer } \\
\text { communication }\end{array}$ & $\begin{array}{l}1=\text { "Once a week"; } \\
0=\text { "Once a month or never" }\end{array}$ \\
\hline $\begin{array}{l}\text { Communication with } \\
\text { suppliers }\end{array}$ & $\begin{array}{l}1 \text { = "Once a month"; } \\
0=\text { "Once a week or never" }\end{array}$ \\
\hline Institution support & $\begin{array}{l}1=\text { "No, we don't have had support"; } \\
0=\text { "Yes, we have had support" }\end{array}$ \\
\hline Economic sector & $\begin{array}{l}1=\text { "Services"; } \\
0=\text { "Commerce" }\end{array}$ \\
\hline Type of company & $\begin{array}{l}1=\text { "S.A.S"; } \\
0=\text { "Others" }\end{array}$ \\
\hline ICT Invest & $\begin{array}{l}1 \text { = "Yes, we have invested"; } \\
0=\text { "No, we don't invest" }\end{array}$ \\
\hline Financial management & $\begin{array}{l}1=\text { "In house"; } \\
0=\text { "3rd party" }\end{array}$ \\
\hline Financial situation & $\begin{array}{l}1 \text { = "Very precisely"; } \\
0=\text { "Great features or little" }\end{array}$ \\
\hline
\end{tabular}

Source: Authors

The results of the econometric model for each of the explanatory variables taken into account are described further.

Regarding the variable number of employees, it was found that as personnel increases in the companies, it is related to an increase in the probability of having gross sales of more than 100 million pesos. Punctually, companies with a staff between 10 and 20 employees and more than 20 employees have to increase the probability of reaching said sales between 0.12 and 0.41 percentage points, respectively.

The results also suggest that the frequency with which the companies communicate with their suppliers positively affects the probability of sales in reference, since those who communicate once 
Table 5. Results of the econometric model

Source: Authors.

\begin{tabular}{|c|c|c|c|c|c|c|c|c|}
\hline Variables & (1) & (2) & (3) & (4) & (5) & (6) & (7) & (8) \\
\hline \multirow{2}{*}{$\begin{array}{l}\text { Number of employees } \\
\text { [2 = "Between } 10 \text { and } 20 \\
\text { employees"] }\end{array}$} & $0.165^{* * *}$ & $0.171^{* * *}$ & $0.144^{* * *}$ & $0.0143^{* * *}$ & $0.0144^{* * *}$ & $0.0145^{* * *}$ & $0.141^{* * *}$ & $0.121^{* * *}$ \\
\hline & -0.046 & -0.047 & -0.043 & -0.043 & -0.043 & -0.044 & -0.044 & -0.041 \\
\hline \multirow{2}{*}{$\begin{array}{l}\text { Number of employees [ } 3=\text { "20 } \\
\text { or more employees"] }\end{array}$} & $0.407^{* * *}$ & $0.410 * * *$ & $0.351^{* * *}$ & $0.350 * * *$ & $0.351^{* * *}$ & $0.351^{* * *}$ & $0.341^{* * *}$ & $0.337 * * *$ \\
\hline & -0.049 & -0.051 & -0.056 & -0.056 & -0.056 & -0.057 & -0.059 & -0.063 \\
\hline \multirow{2}{*}{$\begin{array}{l}\text { Program beneficiary }[1=\text { "Yes, } \\
\text { we have been a beneficiary"] }\end{array}$} & 0.0749 & 0.0665 & -0.00502 & -0.00646 & -0.00202 & -0.00199 & 0.0103 & 0.000175 \\
\hline & -0.052 & -0.052 & -0.072 & -0.072 & -0.07 & -0.07 & -0.069 & -0.078 \\
\hline \multirow{2}{*}{$\begin{array}{l}\text { Customer communication } \\
{[1=\text { "Once a week"] }}\end{array}$} & \multirow{2}{*}{-} & 0.0863 & 0.0234 & 0.0206 & 0.0176 & 0.0174 & 0.0194 & 0.049 \\
\hline & & -0.075 & -0.064 & -0.063 & -0.062 & -0.061 & -0.06 & -0.07 \\
\hline \multirow{2}{*}{$\begin{array}{l}\text { Communication with suppliers } \\
\text { [1 = "Once a month"] }\end{array}$} & \multirow{2}{*}{-} & $0.227 * *$ & $0.206 * *$ & $0.210 * *$ & $0.208 * *$ & $0.207 * *$ & $0.181 * *$ & 0.105 \\
\hline & & -0.103 & -0.093 & -0.093 & -0.094 & -0.094 & -0.085 & -0.075 \\
\hline \multirow{2}{*}{$\begin{array}{l}\text { Institution support [ } 1=\text { "No, we } \\
\text { do not have had support"] }\end{array}$} & \multirow{2}{*}{-} & \multirow{2}{*}{-} & $-0.178 * * *$ & $-0.181 * * *$ & $-0.180 * * *$ & $-0.181 * * *$ & $0.168^{* * *}$ & $-0.146 * *$ \\
\hline & & & -0.065 & -0.065 & -0.065 & -0.065 & -0.062 & -0.061 \\
\hline \multirow{2}{*}{ Economic sector [1 = Services] } & \multirow{2}{*}{-} & \multirow{2}{*}{-} & \multirow{2}{*}{-} & -0.0177 & -0.019 & -0.0193 & -0.0167 & -0.0368 \\
\hline & & & & -0.043 & -0.042 & -0.043 & -0.042 & -0.041 \\
\hline \multirow{2}{*}{ Type of company [1 = "S.A.S."] } & \multirow{2}{*}{-} & \multirow{2}{*}{-} & \multirow{2}{*}{-} & \multirow{2}{*}{-} & -0.0203 & -0.0196 & -0.026 & -0.0286 \\
\hline & & & & & -0.041 & -0.04 & -0.039 & -0.039 \\
\hline \multirow{2}{*}{$\begin{array}{l}\text { ICT Invest [ } 1 \text { = "Yes, we have } \\
\text { invested"] }\end{array}$} & \multirow{2}{*}{-} & \multirow{2}{*}{-} & \multirow{2}{*}{-} & \multirow{2}{*}{-} & \multirow{2}{*}{-} & -0.00473 & 0.00839 & 0.00298 \\
\hline & & & & & & -0.042 & -0.043 & -0.045 \\
\hline \multirow{2}{*}{$\begin{array}{l}\text { Financial management }[1=\text { "In } \\
\text { house"] }\end{array}$} & \multirow{2}{*}{-} & \multirow{2}{*}{-} & \multirow{2}{*}{-} & \multirow{2}{*}{-} & \multirow{2}{*}{-} & \multirow{2}{*}{-} & $-0.0788^{*}$ & -0.0598 \\
\hline & & & & & & & -0.041 & -0.042 \\
\hline Financial situation [1 = "Very & - & - & - & - & - & - & - & $0.157^{* *}$ \\
\hline precisely"] & & & & & & & & -0.061 \\
\hline Observations & 222 & 222 & 222 & 222 & 222 & 222 & 222 & 222 \\
\hline Pseudo $R$-square & 0.294 & 0.334 & 0.382 & 0.383 & 0.384 & 0.384 & 0.399 & 0.438 \\
\hline
\end{tabular}

Note: Level of statistical significance: *** Significant variable at $1 \%, * *$ Significant variable at $5 \%, *$ Significant variable at $10 \%$.

a month with suppliers have an increase in the probability of 0.23 percentage points. The foregoing may be supported to the extent that to meet the demands of the market in terms of marketing and subsequent sale of goods (services), the communication with the suppliers would give the indications of the productive dynamics within the companies.

Another interesting result is that the lack of support from programs aimed at strengthening small and medium-sized enterprises means a reduction of at least 0.15 percentage points in the probability of having sales greater than 100 million. This result demonstrates the importance of generating the socialization strategies for actors that guide the economic activities in certain sectors, since their instruction generates the positive market results.
Finally, the financial management and knowledge of the financial situation of the company affects the probability of having sales in excess of 100 million. The first variable mentioned suggests that those companies that have some sort of separability of functions in the financial field delegated to employees outside the company are more likely to have sales in excess of 100 million; result that could be based from the perspective of corporate finance to the extent that managing the resources of the company itself can lead to results not as efficient as if they are managed by third parties. In the meantime, knowing the company's situation accurately suggests an increase in the said probability, which demonstrates the importance of maintaining constant supervision of its financial structure, which may give a margin of action for possible interventions both at the time of good market results and in bad ones. 


\section{CONCLUSION}

SMEs in the commerce and services sector are the main generators of market diversification and unemployment reduction, which allows increasing and boosting the GDP of the countries, although as the years go by, they tend to increase, they are not being created under an organizational structure that allows them to be competitive and, therefore, to sustain themselves in the market.

Specifically, in the Municipality of Palmira, Valle del Cauca, SMEs do not have a well-established strategic aim or good strategic planning, which is why their level of competitiveness is not representative but they remain in the market because they implement the traditional 5 P's of marketing (price, product, promotion, place, people), although presenting the flaws in the constant staff training and in the technification of their facilities.

The companies in Palmira work towards increasing their level of competitiveness, strengthening the quality, efficiency and effectiveness, productivity, technology, among other factors. However, even though innovation is the main index to measure the competitiveness in most companies in the world, in case of Palmira, it is not carried out permanently and inherently in the processes, they do not do it constantly, they opt for it when they consider that their products or processes are lagging behind, or have become obsolete.

Since the commerce and services sector does not require much initial investment, it tends to be supported by government entities and some educational institutions more because, for the same reason, they tend to create much of the same without adding a differentiating factor. Due to the aforementioned characteristics, it is concluded that one of the reasons why the competitive advantage of these companies is weak, based on the definition given by Porter (2015), is the lack of research and planning, which leads to non-innovation. Therefore, habitually these do not differ from their competitors, which generates a lack of creation of a unique offer that makes their customers prefer them.

\section{REFERENCES}

1. Ahumada, E., \& Perusquia, M. (2015). Inteligencia de negocios: estrategia para el desarrollo de competitividad en empresas de base tecnología. Contaduría y Administración, 61, 127-158. http://dx.doi.org/10.1016/j. cya.2015.09.006

2. Akben-Selcuk, E. (2016). Factors Affecting Firm Competitiveness: Evidence from an Emerging Market. International Journal of Financial Studies, 4(9), 2-10. https://doi.org/10.3390/ijfs4020009

3. Almeida, A., \& Vieira, J. (2013). Logistica colaborativa: Um estudo com fornecedores de supermercados de pequeño e medio porte. Revista Gestao Industrual, 9(3), 745-764. Retrieved from https://periodicos.utfpr.edu. br/revistagi/article/view/1445
4. Balcázar, J. (2015). Análisis de casos de los factores potenciales que están incidiendo en el fracaso de las PYMES (Tesis pregrado). Universidad Técnica de Machala. Retrieved from http://repositorio.utmachala.edu.ec/handle/48000/5209

5. Barbosa, A., Souza, A., Chaves, F., \& Santos de Varge, J. (2017). Association between innovation competences and competitiveness in the brazilian electromedical device industry. Gestao and Producao, 25(3), 545-556. https://doi.org/10.1590/0104530X3840-18

6. Batista, N., Kilimnik, Z., \& Reis, M. (2016). Influência dos estilos de liderança na satisfação no trabalho: Um estudo em uma entidade de fins não econômicos. Revista de Gestão e Tecnologia, 6(3), 24-
39. Retrieved from http://navus. sc.senac.br/index.php/navus/article/view/24

7. Bóveda, J. (2004). El Emprendedor y las pequeñas empresas. $R e$ vista futuros, 6(2). Retrieved from https://ru.scribd.com/document/336436338/El-Emprendedor$\mathrm{y}$-Las-Pequenas-Empresas

8. Calantone, R., Cavusgil, S., \& Zhao, Y. (2002). Learing orientation, firm innovation capability and firm performance. Industrial Marketing Management, 31(6), 515-524. https://doi.org/10.1016/S0019. 8501(01)00203-6

9. Cámara de Comercio de Cali. (2016). Balance económico de Cali y Valle del Cauca en el 2016. Cali, Valle del Cauca. Retrieved from http://www.ccc.org.co/file/2017/01/ Balance-economico-de-Cali-y-elValle-del-Cauca-en-2016.pdf 
10. Cámara de Comercio de Palmira. (2016). Anuario estadístico. Palmira, Valle del Cauca. Retrieved from http://www. fundacionprogresamos.org.co/ anuarios_estadisticos/palmira/ anuario_2016/doci.html

11. Cámara de Comercio de Palmira. (2017). Composición empresarial Palmira. Palmira, Valle del Cauca. Retrieved from http:// fundacionprogresamos.org.co/ anuarios_estadisticos/palmira/ anuario_2017/doci.html

12. Colgan, C., \& Baker, C. (2003) A frameworks for assesing cluster development. Economic development quartely, 17(4), 352-366. https://doi.org/10.1177\%2F0891242403256667

13. Confecámaras. (2016). Informe de la dinámica empresarial en Colombia. Retrieved from http:// www.confecamaras.org.co/ phocadownload/2017/Informe din\%C3\%A1mica_empresarial/ Informe_de_Din\%C3\%A1mica Empresarial_I_Trim_2017_V. Final.pdf

14. Congreso de Colombia. (2000). Ley 590 de 2000.

15. Cordero, J., Astudillo, S., Carpio, X., Delgado, J., \& Amón, O. (2011). Análisis de los factores que influyen el emprendimiento y la sostenibilidad de las empresas del área urbana de la ciudad de Cuenca, Ecuador. Maskana, Revista Semestral de la DIUC, 2(2), 27-37. Retrieved from http:// dspace.ucuenca.edu.ec/bitstream/123456789/5412/1/MASKANA\%20si7285\%20\%283\%29. pdf

16. Criollo, C., \& Montoya, J. (2014). Estructuración de una guía metodológica para la identificación $y$ formulación de proyectos productivos como apoyo al fortalecimiento de las mipymes en el departamento del meta (Tesis de Maestría, Universidad Nacional de Colombia). Retrieved from http://www.bdigital.unal.edu. co/49690/1/152577.2015.pdf

17. Cunha, D., \& Moneva, J. (2018). The elaboracion del informe de sostenibilidad: un estudio de caso. Review of business management,
20(4), 533-549. https://doi. org/10.7819/rbgn.v0i0.3948

18. DANE. (2016). Informe de la coyuntura económica Regional. Retrieved from https://www.dane. gov.co/files/icer/2015/ICER_Valle_ del_Cauca2015.pdf

19. De la Cruz, I. \& Morales, J. (2006). Desarrollo de competencias en la Micro, Pequeña, Mediana y Gran empresa en México: Un estudio empírico exploratorio (En las memorias del XI Foro de Investigación). Congreso Internacional de Contaduría, Administración e Informática.

20. Dean, J., Holmes, S., \& Smith, S. (1997). Undestanding business networks: Evidence from the manufacturing and service sectors in australia. Journal of Small Business Management, 18(1), 78-84. Retrieved from https://researchdirect.westernsydney.edu.au/islandora/object/uws:20502

21. Distanont, A., \& Khongmalai, O. (2018). The role of innovation in creating a competitive advantage. Kasetstart journal of social sciences, 1(7). https://doi.org/10.1016/j. kjss.2018.07.009

22. Dominguez, J. (2014). Cerca de 90 mil empresas han cerrado en el ultimo año. Portafolio. Retrieved from https://www.portafolio.co/ negocios/empresas/cerca-90-milempresas-han-cerrado-ano-49120

23. Florez, L. (1998). Comentario al documento "Tendencias del pensamiento económico sobre desarrollo industrial". Centro de Investigaciones para el Desarrollo. Universidad Nacional de Colombia. Retrieved from http:// www.cid.unal.edu.co/files/publications/CID199806vacodo.pdf

24. Fonseca, A., \& Porto, J. (2013). Validação fatorial de escala de atitudes frente a estilos de liderança. Avaliação Psicológica, 12(2), 157-166. Retrieved from http://pepsic.bvsalud.org/scielo.php?script=sci_arttext\&pid $=$ S1677-04712013000200007

25. Fraj, E., Matute, J., \& Melero, I. (2014). Environmental strategies and organizational competitiveness in the hotel industry: the role or learning and innovation as determinants of environmental success. Tourism management, 46 , 30-42. https://doi.org/10.1016/j. tourman.2014.05.009

26. Hernández, M., Mendoza, J., \& Gonzales, L. (2017). Construcción $y$ validez del instrumento de cultura organizacional y competitividad (IOC).

27. Husain, Z., Dayan, M., \& Benedetto, A. (2015). The impact of networking on competitiveness via organizational learning, employee innovativeness, and innovation process: A mediation model. Journal of Engineering and Technology Management, 40, 15-28. http://dx.doi.org/10.1016/j. jengtecman.2016.03.001

28. Kantis, H., Angelli, P., \& Moori, V. (2004). Desarrollo emprendedor: América latina y la experiencia internacional. BID-Fundes Internacional S1.

29. Khakpour, A., Kazemi, M., Tavakkoli, A., \& Fazli, S. (2018). Designing a communicational model between the competitiveness types of small and medium industries in Iran. Industrial engineering and management systems, 17(3), 550-561. Retrieved from https://profdoc.um.ac.ir/paperabstract-1070615.html

30. Latunreng, W., \& Hesti, D. (2018). Organizational cultures in supporting SMEs competitiveness within Indonesian silk industry. International journal of engineering and technology, 7(3), 209-212. https://doi.org/10.14419/ ijet.v7i3.21.17161

31. Lo, M. C., Wah, C. R. J., \& Ramayah, T. (2016). Fatores críticos de sucesso para o desempenho organizacional de PMEs na Malásia: uma abordagem parcial de mínimos quadrados. Revista of business management, 18(61), 370-371. https://doi. org/10.7819/rbgn.v18i61.3058

32. Marín, P. (2015). Factores que afectan la perdurabilidad empresarial en Leticia. Amazonas, Colombia (Tesis Maestría, Universidad Nacional de Colombia). Retrieved from http://www.bdigital.unal.edu. 
co/48483/1/patriciamarinlujan.2015.pdf

33. Martins, D., Costa P., \& Neves, F. (2018). Liderança transformacional e satisfação no trabalho: avaliando a influência de fatores do contexto organizacional e características individuain. Revista Brasileira de Gestão e Negócios, 20(4), 516-532. https:// doi.org/10.7819/rbgn.v0i0.3949

34. Meyer, J., \& Allen, N. (1991). A three component conceptualization of organizational commitment. Human Resource Management Review, 1(1), 61-89. https://doi.org/10.1016/10534822(91)90011-Z

35. Mora, E., Vera, M., \& Melgarejo, Z. (2015). Planeación estratégica y niveles de competitividad de las MiPyMes del sector comercio en Bogotá. Estudios Gerenciales, 31, 79-87. https://doi.org/10.1016/j. estger.2014.08.001

36. Morales, M. E., \& Castellanos, O. (2007). Estrategias del fortalecimiento de las Pyme de base tecnológica a partir del enfoque de competitividad sistémica. Revista Innovar, 17(29).

37. Othman, R., Arshad, R., Abdul, N., \& Mohd, S. (2015). Organizational Resources and Sustained Competitive Advantage of Cooperative Organizations in Malaysia. Procedia - Social and Behavioral Sciences, 170, 120-127. https://doi. org/10.1016/j.sbspro.2015.01.021

38. Peixoto de Vaiva, W. (2005). Avaliação da eficácia de uma campanha de propaganda: um estudo empírico. Revista Brasileña de Gestion de Negocios, 7(17).

39. Porter, M. (2008). Las cinco fuerzas competitivas que le dan forma a la estrategia. Harvard Bussiness Review. America Latina.

40. Porter, M. (2015). Ventaja Competitiva. México: Grupo editorial patria.

41. Priego, A., Manzaneque, M., \& Banegas, R. (2013). Análisis del cese de la actividad empresarial a través del comportamiento de los Stakeholders. Universidad de Castilla la Mancha, 16/17, 55-83.
42. Rauch, A., Wiklund, J., Lumpkin, G. T., \& Frese, M. (2009). Entrepreneurial orientation and el desempeño del negocio: una evaluación de la investigación temprana y generada para el futuro. Entrepreneurship Theory and Practice, 33(3), 761-787.

43. Rivera, C., \& Rojas, K. (2019). Identificacion de variables para el diseño de un modelo de asistencia tecnica empresarial para las Pymes del sector servicio en la ciudad de Palmira. Trabajo de Grado. Universidad Santiago de Cali.

44. Rivera, H. (2012). Perdurabilidad empresarial: Conceptos, estudios, hallazgos. Colombia, Facultad de Administración: Universidad del Rosario.

45. Rivera, M. (2015). Determinant Factors for Small Business to Achieve Innovation, High Performance and Competitiveness: Organizational Learning and Leadership Style. Procedia - Social and Behavioral Sciences, 169, 43-52. https://doi.org/10.1016/j. sbspro.2015.01.284

46. Rubio, A., \& Aragón, A. (2006). Factores explicativos del éxito competitivo. un estudio empírico de la Pyme. Universidad de Murcia, Cuadernos de Gestión, 2(1). Retrieved from https://addi.ehu. es/handle/10810/7024

47. Rueda, J. (2014). Diseño de un modelo de planeación estratégica soportado en el sistema gerencial de Kaplan y Norton (Tesis

Maestría, Universidad Nacional de Colombia). Retrieved from http://bdigital.unal.edu. co/45972/1/1072655924.2013.pdf

48. Saavedra, M. L. (2012). Una propuesta para la determinación de la competitividad en la pyme latinoamericana. Pensamiento y Gestión, 33, 93-124. Retrieved from https://www.researchgate. net/publication/260772740_Una_ propuesta_para_la_determinacion_de_la_competitividad_en_la_ pyme_latinoamericana

49. Sanchez, J., \& Jimenez, P. (2007). La cooperación empresarial como estrategia de crecimiento: Motivos de su formación, ventajas e inconvenientes. Decisiones
Organizativas. Retrieved from https://dialnet.unirioja.es/servlet/ articulo codigo $=2499441$

50. Santos, M., Lopez J., \& Trespalacios, J. (2010). How organizational learning affects a firm's flexibility, competitive strategy, and performance. Journal of Business Research, 65, 1079-1089. https://doi. org/10.1016/j.jbusres.2011.09.002

51. Solleiro, J. L., \& Castañón, R. (2005). Competitividad y sistemas de innovación: los retos para la inserción de México en el contexto global. Globalización, ciencia y tecnología, 165-197. 